\title{
EKSISTENSI SUFISME SASAK DALAM NOVEL SANGGARGURI DAN PERANNYA DALAM KEHIDUPAN MASYARAKAT DI PULAU LOMBOK
}

\author{
Siti Maryam \\ Universitas Mataram \\ Pos-el: sitimaryam1402@gmail.com
}

\begin{abstract}
A bstrak
Sufisme Sasak merupakan salah satu konsep yang mengatur nilai dan norma berkehidupan, khususnya dalam tatanan masyarakat suku Sasak di Pulau Lombok. Eksistensinya pun semakin universal ketika tertuang dalam wujud karya sastra berupa novel yang berjudul Sanggarguri. Melalui novel tersebut, penanaman dan pengembangan karakter sufisme suku Sasak terus dilakukan sehingga peran sufisme Sasak tersebut dapat dirasakan manfaatnya dalam kehidupan masyarakat. Oleh sebab itu, penelitian ini bertujuan mendeskripsikan wujud sufismeSasak dalam novel tersebut beserta berbagai perannya dalam kehidupan masyarakat di Pulau Lombok agar diketahui dan diwujudkan dalam kehidupan nyata oleh seluruh masyarakat. Dalam hal ini, teori semiotik Roland Barthes menjadi al at bedah penel itian yang dilakukan dengan metodeobservasi berupa wawancara terhadap penulis novel Sanggarguri dan studi kepustakaan. A dapun penelitian yang dilakukan ini menghasilkan data berupa 10 jenis kembang atau bunga yang menjadi simbolisasi konsep sufisme Sasak dalam novel Sanggarguri. Kembang-kembang tersebut selain bermakna konseptual atau denotatif, juga mengandung hikmah sufisme yang dapat dijadikan pedoman bagi masyarakat. Selain itu, peranan sufisme Sasak dalam kehidupan masyarakat di Pulau Lombok terdiri atas perannyadalam bidang pendidikan, dakwah, sosial, dan budaya. Dengan demikian, konsep sufisme Sasak merupakan konsep yang tidak hanya dapat menjadi pedoman atau acuan masyarakat Sasak, tetapi juga bernilai universal yang artinya dapat dipedomani pula oleh masyarakat di luar suku Sasak atau luar Pulau Lombok.
\end{abstract}

Kata kunci: sufismeSasak, Sanggarguri, Pulau Lombok

\begin{abstract}
Sasak Sufism is one concept that set the values and norms, in particular the ones in public order Sasak in Lombok island. Its existence moreuniversal when it is stated in theform of literary works in the form of the novel Sanggarguri. Thenovel through planting and character development Sufism Sasak continueso that the role of Sufism theSasak can be felt its benefits in people's lives. Therefore, this study aims to describe a form of Sufism Sasak of thenovel, al ong with a variety of its rolein the life of society on theisland of Lombok in order to be known and manifested in real life by the entire community. In this case, the theory of R oland Barthes semiotik becamesurgical tools research doneby the method of observation in theform of theinterview against theauthor of thenovel Sanggarguri and thestudy of librarianship. A s for theresearch conducted this generates data in the form of 10 kinds of flower or flowers be symbolizing the concept of Sufism Sasak in the novel Sanggarguri. Flower-theflower in addition to conceptual or in den otativemeaning, al so contains thewisdom of Sufism that can beused as a guidelinefor the community. In addition, the roleof Sufism Sasak in Lombok island in the people's life consists of his role in the fields of education, social, and cultural events. Thus, the concept of Sufism is the concept that theSasak can not only bea guidelineor referenceSasak community, but worth theuniversal which means that it can bedipedomani by thecommunity outsidetheSasak Lombok island or outside.
\end{abstract}

Keyw ords: Sufism, Sanggarguri, Sasak Lombok island

Eksistensi Sufisme Sasak dalam Novel Sanggarguri dan Perannya dalam Kehidupan Masyarakat ... 


\section{PEN DAHULUAN}

Kekayaan tradisi dan budaya di Indonesia tidak bisa dimungkiri lagi dan sudah mendapat pengakuan dunia. Kekayaan tersebut tetap terpelihara hingga saat ini, dan menjadi suatu kebanggaan bagi bangsa Indonesia. Keterawatan tradisi dan budaya tersebut tidak lepas dari kukuhnya semangat menjaga dan melestarikan apa yang dimiliki oleh masyarakat di masingmasing daerah sebagai pemilik tradisi dan budaya tersebut. Selain itu, peran serta pemerintah melalui pihak yang terkait semakin menguatkan posisi tradisi dan budaya daerah se bagai sesuatu yang harus terus dijaga, dikukuhkan, dan dirawat agar tetap lestari bagi generasi selanjutnya.

Satu hal yang juga menjadi penting untuk diperhatikan dalam rangka mengukuhkan keberadaan tradisi dan budaya masyarakat yaitu terdapatnya nilai-nilai dan norma-norma yang agung dan luhur pada setiap wujud ke arifan lokal masyarakat. Nilai dan norma yang terdapat dalam kearifan lokal melalui aspek tradisi dan budaya telah menjadi pedoman dan tolok ukur pengembangan karakter masyarakat yang ada di tiap-tiap daerah. Begitu pula de ngan masyarakat suku Sasak yang hidup dan mendiami Pulau Lombok.

Masyarakat suku Sasak sebagai salah satu bagian dari kemajemukan sosial di Indonesia telah mengejewantahkan diri melalui kearifan lokal yang dimilikinya. Konsep tradisi dan budaya Sasak masih hidup berdampingan secara baik bersama aspek lainnya, salah satunya agama. Hal ini tentu menjadi keunikan tersendiri dalam kaitannya dengan kehidupan sosial masyarakat Indonesia yang terdiri atas beragam budaya, agama, suku, dan golongan. A rtinya, nilai dan norma budaya yang dimiliki oleh masyarakat Sasak masih terawat dengan baik disertai dengan kuatnya nilai dan norma agama yang dianutnya.

Dalam hal ini, salah satu dampak atau efek yang terjadi ketika konsep kebudayaan Sasak bertemu dan menyatu dengan konteks kea- gamaan (Islam dan Hindu) yang dianut oleh sebagian besar masyarakat Sasak ialah lahirnya konsep sufisme Sasak. Konsep tersebut pada intinya berkaitan dengan penanaman dan pengembangan nilai dan norma kebenaran yang ada di tengah masyarakat melalui representasi aspek budaya dan agama. Kolaborasi budaya dan agama pada masyarakat Sasak tidak mendapat pertentangan atau menjadi penyebab konflik yang berkepanjangan. Bahkan, kedua aspek tersebut semakin erat dan saling melengkapi dalam rangka mengukuhkan nilai dan norma positif dalam kehidupan generasi Sasak dari masa ke masa.

A dapun sufisme Sasak yang secara universal dipahami oleh masyarakat yaitu konsep kehidupan masyarakat suku Sasak yang menyandarkan segenap aktivitasnya pada aspek ketauhidan yang di dalamnya dirangkaikan pula dengan sikap-sikap kultural yang telah lama menjadi tradisi masyarakat Sasak. Masyarakat Sasak sudah mengenal adanya konsep ketuhanan sebagai wujud perjalanan alam semesta sejak lama. Begitu pula dengan aspek kultural yang telah mendarah daging dalam kehidupan masyarakat Sasak secara turuntemurun. Oleh sebab itu, sufisme Sasak lahir sebagai perwujudan yang kuat terkait dengan kehidupan beragama dan kehidupan berbudaya yang dijadikan pedoman oleh masyarakat suku Sasak.

Berbicara sufisme Sasak, tidak hanya terbatas pada konsep nilai dan norma yang terkandung di dalamnya, tetapi juga sudah mulai menjadi komoditas yang eksistensinya dituangkan ke dalam karya sastra. Perwujudan sufismeSasak dalam suatu karya sastra khususnya novel telah dilakukan oleh salah seorang pengarang asli Sasak (Lombok) yang bernama Lalu Agus Fathurrahman. Dalam novelnya, digambarkan mengenai kehidupan beragama dan berbudaya suku Sasak dalam konsep sufismeSasak melalui simbolisasi kembang (bunga).

Secara kontekstual, kembang atau bunga merupakan salah satu bagian alam yang men- 
jadi bahan pembelajaran yang sering digunakan oleh masyarakat suku Sasak. Sebab, bagi masyarakat suku Sasak, kembang atau bunga merupakan representasi dari kesadaran diri sebagai makhluk ciptaan Tuhan yang harus hidup selaras dengan alam, memberi warna dan aroma pada kebudayaan, dan bermanfaat bagi semua pihak sesuai dengan ajaran agama. Simbolisasi kembang inilah yang dipilih untuk digunakan oleh pengarang dalam rangka menyampaikan pesan sufismeSasak melalui karya sastra. Pengarang tentu paham betul bahwa karya sastra bukan hanya sebagai alat atau me dia hiburan bagi masyarakat, melainkan juga sebagai alat, media, dan wadah pembelajaran atau pendidikan, termasuk pendidikan mengenai nilai dan norma yang menjadi pedoman kehidupan bermasyarakat.

Berdasarkan hal tersebut, selain untuk terus menguatkan posisi sufisme Sasak di tengah kehidupan masyarakat yang saat ini seolah mulai kehilangan pedoman, kemunculan novel yang berjudul Sanggarguri tersebut menjadi "angin segar" bagi para pembelajar budaya dan agama. Tentunya, eksistensi sufisme Sasak yang dituangkan dalam wujud karya sastra tersebut harus memiliki tempat di masyarakat, be rupa perannya dalam setiap sisi kehidupan bermasyarakat. Peranan sufismeSasak tersebutlah yang nantinya semakin menguatkan posisi sufisme Sasak sebagai pedoman dalam menjalani hidup dan kehidupan suku Sasak khususnya, dan pihak-pihak lainnya secara umum.

Dalam hal ini, sebagai suatu kajian ilmiah, penelitian ini tidak berdiri sendiri sehingga membutuhkan beberapa konsep yang dapat menjadi rujukan dan referensi penelitian. Re ferensi yang dimaksud terdiri atas beberapa penelitian yang pernah dilakukan oleh peneliti sebelumnya. Kemudian, referensi penting lainnya yaitu berkaitan dengan teori yang digunakan dalam penelitian ini.

Penelitian pertama yang menjadi rujukan dalam penelitian ini yaitu yang dilakukan oleh Handayani (2016) dengan judul “Aspek Moral dalam Novel Biru karya Fira Basuki: Pendekatan Semiotik". Penelitian berupa analisis semiotik terhadap novel Biru, menunjukkan bahwa; (1) aspek agama sebagai penentram batin yaitu tindakan yang dilakukan untuk lebih mendekatkan diri kepada Tuhan sang pencipta, (2) aspek kepedulian terhadap lingkungan yaitu suatu tindakan peduli terhadap pencemaran lingkungan, (3) aspek korupsi dan memperkaya diri yaitu tindakan yang dilakukan tidak hanya karena alasan ekonomi, tetapi juga sudah menjadi budaya, khususnya di Indonesia, (4) aspek perselingkuhan, alasan perselingkuhan adalah tidak ada kecocokan antara keduanya, (5) aspek pelecehan yaitu pelecehan terhadap perempuan yang tidak hanya terbatas pada gerakan fisik, tetapi juga sudah mengarah padatindakan kriminal yaitu pemerkosaan.

Selanjutnya, penelitian yang dilakukan oleh Imron (2013) juga menjadi rujukan penelitian ini dengan judul "Nilai Pendidikan Multikultural dalam Novel Burung-Burung Rantau." Hasil penelitian tersebut yaitu terdapat wujud nilai pendidikan multikultural dalam novel Burung-Burung Rantau karyaY.B. Mangunwijaya. Adapun wujud yang dimaksud yaitu munculnya generasi muda pasca-Indonesia yang berorientasi pada multikulturalisme. Generasi pasca-Indonesia merupakan Burung-Burung Rantau yang bebas untuk menemukan dunianya sendiri sehingga cenderung generasi muda melepaskan diri dari nilai budaya dan tradisi etnisnya dengan alasan agar bebas berkreativitas. Multikulturalisme mencerminkan fenomena munculnya budaya lokal dan nasional, barat dan timur, serta multikulturalismemampu menembus batas etnis, agama, kebangsaan, kasta, dan gender.

Penelitian lainnya yang juga dijadikan rujukan dalam penelitian ini adalah penelitian yang dilakukan oleh Badrin (2011) dengan judul “Potret Perjuangan Tokoh Utama dan Nilai Didik dalam Novel Guru Dane Karya Salman Faris". Adapun simpulan penelitian tersebut yaitu (1) Novel Guru D ane terdiri atas 
beberapa unsur yang saling melengkapi, yakni tema, penokohan, latar, amanat, dan alur; (2) bentuk perjuangan tokoh utama untuk membangkitkan harga diri orang Sasak dengan menjunjung tinggi nilai pluralitas, humanitas, dan kekuatan identititas yang dikelompokkan menjadi: (a) membangun kesadaran kognitif tentang kemanusiaan, (b) membangun kesadaran sosial, (c) meruntuhkan keangkuhan atau kebesaran yang bergantung kepada benda-benda mistik, (d) menanamkan kesadaran kelas, dan (e) menanamkan sifat kesatria se bagai orang Sasak.

Mencermati beberapa penelitian yang menjadi rujukan tersebut sebagai perbandingan, penelitian-penelitian tersebut memiliki persamaan dan perbedaan dengan penelitian yang dilakukan ini. Adapun beberapa persamaan yang dimaksud, yaitu (1) tiga penelitian sebelumnya dengan penelitian ini menggunakan novel sebagai objek kajiannya; (2) penelitian ketiga dengan penelitian ini sama-sama mengangkat konteks kehidupan suku Sasak sebagai bahan kajian; (3) penelitian pertama dengan penelitian ini sama-sama menggunakan teori semiotik sebagai alat kaji; dan (4) secara garis besar, me tode yang digunakan dalam penelitian sebelumnya dengan penelitian ini sama, yaitu metode observasi dan studi kepustakaan.

Sementara itu, perbedaan antara penelitian-penelitian sebelumnya dengan penelitian yang dilakukan ini terletak pada aspek kajiannya. Pada penelitian pertama, yang menjadi aspek kajiannya ialah aspek moral yang terdapat dalam novel. Kemudian, penelitian kedua mengkaji nilai pendidikan multikultural dalam novel. Selanjutnya, penelitian ketiga mengangkat perjuangan tokoh dan nilai pendidikan yang terdapat dalam novel. Adapun pada penelitian yang dilakukan ini, yang menjadi aspek kajian ialah konsep sufistik yang dimiliki oleh suku Sasak yang terdapat dalam suatu karya sastra berupa novel.

\section{TEORI DAN METODE}

Selain itu, penelitian yang baik tentunya dilandasi oleh beberapa konsep teoretis yang menjadi pedoman atau referensi dalam pelaksanaannya. Adapun dalam penelitian ini, terdapat beberapa konsep teoretisyang menjadi referensi berdasarkan pendapat para ahli pada tiap-tiap konteks. Konsep-konsep teoretis yang dimaksud ialah sufisme, suku Sasak, sufisme suku Sasak, novel Sanggarguri dan semiotik.

Sufisme berasal dari kata Al-Tasawuf yang dapat dilihat dari dua segi, yakni segi etimologis dan segi terminologis. Dari segi linguistik (etimologis), pandangan para ulama berbeda-beda mengenai makna kata tasawwuf. Secara etimologi, kata tasawuf atau sufisme (sufi) berasal dari bahasa Arab (Tashawwafa-yatashaw wafutashawwufan) yang berarti bulu domba, barisan, jernih, dan masih banyak lagi arti lainnya menurut pendapat beberapa ulama (Mahjuddin, 2015:37).

Selain itu, sufistik berasal dari kata sufi (shufi) secara harfiah berakar dari tiga huruf A rab, yaitu shad, wawu, dan fa yang diartikan beraneka ragam, misalnya shafu berarti bersih, atau shafa juga berarti bersih (Suriadin, 2014: 28). A da pula suffah yang berarti sebuah kamar di samping masjid Rasulullah di Madinah yang tersedia untuk sahabat-sahabatnya yang miskin tetapi tebal imannya. Sufi juga dari bahasa Yunani, diambil dari kata sophos, yang artinya bijaksana (Afifuddin, 2013:17).

Namun demikian, dari banyaknya perdebatan di kalangan ahli agama dan ahli bahasa, makna tasawwuf yang paling dapat diterima adalah kata yang diidentikkan kepada orang yang selalu berpakaian suph (wol) dari bulu domba. Makna ini didukung oleh kenyataan sejarah bahwa komunitas sufi pertama kali muncul dari Bashrah, dan yang pertama kali membangun perkumpulan sufi adalah kelompok Abdul Wahid bin Zaid, pengikut Hasan Basri yang selalu memakai pakaian tersebut. Pada saat itu pula di Basrah terdapat perkembangan penganut yang sangat kuat 
tentang konsep-konsep Zuhud, U baddah, Khauf, dan konsep-konsep lainnya (Harapandi, 2004: 125-126).

A papun asalnya, istilah tasawuf berarti orang-orang yang tertarik dan intens dengan pengetahuan-pengetahuan yang terkait dengan batin seseorang. Dengan demikian, orangorang tersebut mencari jalan atau praktikpraktik kearah kesadaran dan pencerahan diri secara terus-menerus tanpa henti mengadakan muraqabah dan kontemplasi dalam mendekatkan dirinya kepadaA Ilah Yang M aha Bijaksana (Harapandi, 2004:127).

Masih terkait dengan pengertian sufisme, seorang tokoh sufi yang lain, yakni Syaikh Ibnu Ajiba (1809 M) menjelaskan bahwa sufisme adalah pengetahuan yang dipelajari seseorang agar dapat berlaku sesuai dengan kehendak Allah melalui penjernihan hati dan membuatnya senang terhadap perbuatan-perbuatan yang baik (A min, 2014:197). Istilah sufi pun dimaksudkan sebagai satu kategori penyifatan dimensi esoteris ajaran Islam. Kata tasawuf terkait langsung dengan esoterisme atau dimensi dalam dan rahasia ajaran Islam itu sendiri (Jumantoro, 2005:208). Shufi juga sebagai sebuah istilah bermakna membersihkan hati dari apa yang mengganggu perasaan kebanyakan makhluk. Pembersihan tersebut dengan cara berjuang meninggalkan pengaruh nafsu, mendekati sifat-sifat suci spiritual, dan bergantung pada ilmu-ilmu hakikat (Supaat, 2010:181).

Berdasarkan beberapa pendapat di atas, dapat disimpulkan bahwa sufisme merupakan akar dari kata tasawu yang berarti suatu pengetahuan yang memelajari tentang bagaimana jalan bagi seorang muslim dalam upaya mendekatkan diri kepada sang Maha Pencipta, Allah Swt. Hal tersebut dilakukan dengan mempergiat amalan-amalan berupa zikrullah, memperhalus mata hati dan nurani untuk selalu me ngingat kebesaran Allah Swt, menghilangkan sifat hawa nafsu duniawi yang merusak keimanan, serta meyucikan hati dan pikiran dari sifat-sifat dan perilaku yang mengarah kepada perbuatan dosa.

Selanjutnya, suku Sasak merupakan suku bangsa yang mendiami Pulau Lombok dan menggunakan bahasa Sasak sebagai bahasa daerahnya dalam aktivitas sehari-hari. Suku Sasak tersebar di lima kabupaten dan kota yang ada di Pulau Lombok. Populasi terbesar suku Sasak terdapat di Kabupaten Lombok Tengah, Lombok Timur, Lombok Utara, Lombok Barat, dan Kota Mataram. Dalam kehidupannya, masyarakat Sasak senantiasa menjunjung tinggi empat konsep, yaitu persaudaraan, kesetaraan, kesederhanaan, dan persatuan. Selain itu, suku Sasak sebagai bagian dari umat beragama juga mengedepankan nilai dan norma yang dilandasi oleh konsep beragama disertai dengan konsep tradisi budaya yang masih dipertahankan. Adapun kombinasi kehidupan beragama dengan situasi kebudayaan tersebut melahirkan satu konsep penting dalam kehidupan suku Sasak yang tergambar dalam lingkup sufistik.

Kemudian, sufismesuku Sasak merupakan konsep yang dimiliki masyarakat Sasak yang berlandaskan pada roh atau spirit tauhid. Spirit tauhid merupakan landasan atau asas dalam melahirkan konsep tentang cara berpikir, bersikap, dan bertindak orang Sasak dalam kehidupan sehari-hari. Dalam konsep kosmologis, dasar atau asas yang digunakan sebagai rujukan dalam memahami spirit tauhid ini adalah tasawuf Islam atau tasawuf akidah, dan tasawuf falsafi (Fathurrahman, 2017:102).

Spirit untuk bangsa manapun adalah hal yang sangat penting bagi landasan atau asas dalam cara berpikir, bertindak, ataupun bersikap. Demikian pula dengan suku Sasak yang sangat meyakini bahwa spirit utama dalam prikehidupan sehari-hari adalah spirit tauhid. Spirit tauhid inilah yang melahirkan kesadaran tauhid. Kesadaran tauhid kemudian tergambar pada konsep kosmologis tauhid yang menyatakan bahwa segala sesuatu di alam raya ini asalusulnya bersumber dari Allah Swt. Allah yang 
Maha menetukan segala sesuatu yang terjadi di alam raya ini. Pernyataan tentang konsep kosmologis tauhid ini disebut sebagai kausa prima atau sangkan paran dalam istilah tasawuf nusantara.

Keyakinan dan kesadaran tauhid inilah yang kemudian melahirkan kesadaran diri sebagai makhluk atau kesadaran sebagai panjak (hamba) dalam konsep sufistik Sasak. Kesadaran sebagai panjak tersebut yang kemudian berimplikasi menjadi akidah dalam perilaku antropologis kehidupan orang Sasak sehari-hari. Perilaku sebagai akidah yang tampak dalam kehidupan adalah sikap dalam memandang dan menghargai sesama makhluk ciptaan, dalam hal ini terdapat pola hubungan yang disebut dengan pola hubungan pengkosmos (Fathurrahman, 2017:104). Pola hubungan pengkosmos ini mengatur bagaimana hubungan manusia dengan makhluk-makhluk lain, serta dengan semua unsur yang terdapat di alam seperti tanah, air, api, dan udara. Dengan pola hubungan pengkosmos seperti inilah, manusia Sasak memiliki pandangan bahwa semua makhluk Allah di bumi ini adalah ibarat satu keluarga dan sama-sama berstatus sebagai panjak Allah di muka bumi.

Penghidupan suku Sasak senantiasa bercermin pada tanah atau bumi. Tanah atau bumi bagi orang Sasak ibarat keluarga yang harus dihidupi. Jika tanah ditelantarkan dan tidak digarap, tanah akan mati. Sebaliknya, jika tanah digarap dan dihidupi, pada gilirannya tanah akan menghidupi manusia. Selain itu, bidang lain yang menjadi penghidupan orang Sasak adalah usaha berdagang. Dalam konsep sufisme Sasak, usaha dagang ini lebih bersifat kepada membantu sesama atau nulung batur. Semua itu harus bermuara kepada hidup yang bermakna atau kebermaknaan. Hidup yang bermakna dapat dijalani dengan konsep pemole dan semaiq. Setiap diri orang Sasak senantiasa memuliakan tanah, memuliakan orang dan berperilaku dengan konsep semaiq, yakni sikap dan perilaku yang tidak berlebih-lebihan. Inilah yang dimaksud dengan cara hidup sufisme Sasak.

Konsep sufisme Sasak juga kaya dengan perlambang atau simbol (Yamin, 2014:93). Contoh yang dapat dikemukakan di sini adalah gunung. Gunung bagi orang Sasak adalah ceruk tertinggi di bumi yang bersentuhan langsung dengan benda langit sehingga disebut "tiang langit". Sebagai tiang langit, tentunya gunung dekat dengan bulan. Bulan dalam konsep orang Sasak merupakan perlambang dari insan kamil. Insan kamil itu seperti bulan yang tidak mengeluarkan cahaya tetapi mendapatkan cahaya dari sumber cahaya, yaitu matahari. Oleh karena itu, masyarakat Sasak selalu berharap untuk mendapatkan cahaya dari sumber cahaya agar menjadi insan kamil atau dalam bahasa Qurannya; nurun ala nuri. Jadi, semua perlambang-perlambang atau simbol itu semua kembali kepada konsep Sasak sebagai sebuah pemikiran tasawuf. Tasawuf Sasak telah ada sejak bangsa Sasak ada dan berangkat dari pemikiran kosmologis dan kesadaran Tauhid.

Jadi, esensi yang paling dasar dari kesadaran diri orang Sasak itu adalah kesadaran diri sebagai panjak atau makhluk. Kemudian yang harus dipahami dari kesadaran diri sebagai panjak ini adalah bahwa pengabdian hidup orang Sasak adalah untuk menemukan jalan kembali atau langan uleq. Usaha pencarian ini kemudian yang menjadi cara dan jalan hidup. Cara hidup orang Sasak dari pemikiran kosmologis ini melahirkan cara berpikir, cara berkata, cara bertindak, dan cara bersikap. Tujuannya adalah untuk mencari dan menemukan jalan kembali yang disebut dalam konsep tasawuf Sasak sebagai D aya atau D aye. D aya dalam hal ini bermakna segala sesuatu yang melahirkan spirit. Dapat juga diartikan sebagai jantung atau kekuatan sehingga apabila menyebutkan orang mati itu dapat digunakan kalimat Dia sudah bedaya, bedaya berarti kembali kepada yang memberi jantung atau memberi hidup (Wachid, 2013:40). 
Adapun objek penelitian ini adalah novel Sanggarguri merupakan novel yang ditulis oleh pengarang asli Lombok (Sasak) bernama Lalu Agus Fathurrahman. Pengarang yang sekaligus salah satu tenaga kependidikan di Universitas Mataram (NTB) tersebut menyajikan novel Sanggarguri berdasarkan fenomena yang terjadi di tengah masyarakat, khususnya masyarakat suku Sasak terkait dengan hilangnya identitas dan nilai lokalitas yang disebabkan oleh pesatnya perkembangan zaman. Sanggarguri yang merupakan novel kebudayaan bercitarasa lokal tersebut memuat nilai dan norma suku Sasak yang disimbolkan dengan beberapa jenis kembang atau bunga (Effendi, 2017:145).

Di Pulau Lombok, kembang atau bunga tersebut sebagian besar merupakan tumbuhan yang sudah langka, keberadaannya hanya pada tempat tertentu, misalnya di Gunung Rinjani. Namun demikian, secara garis besar novel yang ditulis sejak 2011 berdasarkan pengalaman kultural dan spiritual tersebut mencoba mengingatkan kembali masyarakat suku Sasak akan pedoman kehidupan yang harus mereka gunakan, baik sebagai penguat sistem tradisi dan agama yang dijalani sejak lama maupun untuk beradaptasi pada perkembangan era digital seperti saat ini.

Selanjutnya, teori semiotik menjadi landasan dalam penelitian ini. Teori semiotik merupakan perkembangan dari teori strukturalisme. Berdasarkan hal tersebut, untuk menganalisis karya sastra, selain berdasarkan strukturalisme, diperlukan juga analisis berdasarkan teori lain, yang identik dengan teori ini ialah teori semiotika. Strukturalisme dan semiotika sebagai dua teori yang identik, strukturalismememusatkan perhatian pada karya, sedangkan semiotika pada tanda (Simon, 2014:204). Dalam hal ini, untuk menemukan makna suatu karya, analisis strukturalisme harus dilanjutkan dengan analisis semiotika. Secara definitif, menurut Cobley dan Janz (Ratna, 2011:97) semiotika berasal dari kata seme, bahasa Yunani yang berarti penafsir tanda. Literatur Iain menjelaskan bahwa semiotika berasal dari kata semion, yang berarti tanda. Dalam pengertian yang lebih luas se bagai teori, semiotika berarti studi sistematis mengenai produksi dan interpretasi tanda.

Semiotika (semiotics) didefinisikan oleh de Saussure sebagai ilmu atau metode analisis untuk mengkaji tanda. Sementara itu, menurut Preminger (Jabrohim, 2003:68), semiotika adalah ilmu tentang tanda-tanda. IImu ini menganggap bahwa fenomena sosial (masyarakat) dan kebudayaan itu merupakan tanda-tanda. Semiotik memelajari sistem-sistem, aturanaturan, dan konvensi-konvensi yang memungkinkan tanda-tanda tersebut mempunyai arti. Pendapat ini sejalan dengan Nurgiyantoro (2010:40) yang menyatakan bahwa makna yang ditentukan oleh konvensinya karya sastra merupakan tanda-tanda yang bermakna. Tanda mempunyai dua aspek, yaitu penanda (signifier) dan petanda (signified). Penanda adalah bentuk formalnya yang menandai sesuatu yang disebut petanda, sedangkan petanda adalah sesuatu yang ditandai oleh penanda itu, yaitu artinya (Sunardi, 2012:71).

A dapun semiotik yang dimaksud dalam penelitian ini adalah teori yang memelajari, memeriksa, memikirkan, dan menguji tandatanda atau simbol yang dianggap mewakili sesuatu objek tentang kehidupan sufisme masyarakat Sasak secara representatif. Secara khusus, teori semiotika yang menjadi landasan pikir penelitian ini ialah yang dikemukakan oleh Roland Barthes dengan konsep denotasi dan konotasinya.

Dalam hal ini, untuk memperoleh hasil penelitian yang optimal dibutuhkan beberapa metode. Penelitian yang dilakukan ini pun menggunakan beberapa metode yang terbagi dalam proses penyediaan atau pengumpulan data, penganalisisan data, dan penyajian hasil penelitian (Siswantoro, 2015:11). Dalam hal penyediaan atau pengumpulan data, metode yang digunakan ialah observasi dengan teknik wawancara terbuka dengan penulis novel Sanggarguri. Selanjutnya dilengkapi dengan 
studi kepustakaan yang terkait dengan konsepkonsep yang dibutuhkan dalam penelitian ini. Pada tahap penganalisisan data, data dianalisis secara deksriptif yang dilandasi oleh teori semiotika Barthes dengan mengkaji simbolisasi kembang atau bunga secara denotatif dan konotatif. Adapun tahap penyajian data hasil penelitian ini menggunakan metode informal atau dengan kata-kata dan kalimat naratif (Endraswara, 2003:59).

\section{HASIL DAN PEMBAHASAN}

Novel Sanggarguri menyajikan simbolisasi kembang atau bunga sebagai analogi sifat dan sikap suku Sasak yang berlandakan nilai sufisme. Berikut ini merupakan hasil penelitian tentang simbolisasi tersebut beserta uraian hikmah sufi yang terkandung di dalamnya.

\section{1) Kembang Gadung}

Secara umum, dalam kajian nilai-nilai sufisme Sasak, kembang mewakili unsur alam yang sarat dengan makna. Kembang adalah salah satu bagian tumbuhan dan salah satu makhluk ciptaan Tuhan selain hewan dan manusia. Keberadaan atau kehadirannya berke dudukan sama dengan makhluk Tuhan yang lain, yakni sebagai makhluk atau panjak dalam istilah sufisme Sasak. Sebagai sesama makhluk atau panjak N eneq (baca: Tuhan), kehadiran kembang juga dalam rangka mengabdi, bertasbih, dan memberikan i'tibar kepada makhluk lain, khususnya manusia tentang nilai-nilai yang baik dalam kehidupan. Kembang Gadung menandakan sifat ilmu orang Sasak. Sifat Kembang Gadung dalam mempelajari sufisme Sasak terkait dengan jenis pohon atau kembang yang sama sekali tidak menarik perhatian orang. Namun di sisi lain, ada orang yang mampu menikmati rupanya bahkan menikmati isinya sampai mabuk karena beracun. Jika Kembang Gadung atau Pohon Gadung ini mampu ditata sedemikian rupa sehingga terjadi komposisi yang apik, penampilan Kembang Gadung akan mampu menarik perhatian.

\section{2) Kembang Rau}

Dalam sufisme Sasak, Kembang Rau mencitrakan hakikat kembang sebagai suatu keindahan. Kembang tetaplah kembang karena di mana pun tempatnya berada, seperti apapun bentuknya, apapun warnanya, dan seberapapun ukurannya, kembang tetaplah indah. Itulah hakikat kembang. Kembang Rau atau kembang ladang. Kembang tumbuh dan hidup di mana-mana, sama halnya dalam sufistik Sasak bahwa dalam kehidupan masyarakat senantiasa ada orang yang selalu memberikan manfaat serta memberikan kesejukan di tempat ia berada. Orang dengan tipe Kembang Rau ini ada di mana-mana, baik di desa maupun di kota. Oleh karena itu, manusia diibaratkan sebagai seorang "peladang" atau seorang "guru agama" di dunia ini. Dengan kata lain, hidup di dunia ini diibaratkan sebagai bekerja untuk ladang akhirat. Jika ingin mempunyai banyak bekal di akhirat, rajin-rajinlah berladang.

\section{3) Kembang Jempiring}

Dalam sufisme Sasak, Kembang Jempiring direfleksikan pada diri manusia, yakni bunganya yang putih bersih melambangkan kesucian atau kejernihan pikiran dan perbuatan yang jujur. Bunganya yang harum, memberi daya tarik pada setiap insan sebagai simbol kewibawaan. Selain bunganya, daunnya yang berwarna hijau melambangkan kesejukan atau ketentraman hati. Semua itu sebagai perlambang untuk menuntun agar manusia senantiasa mengusahakan sikap yang terbaik bagi diri sendiri, lingkungan, dan orang lain. Selain itu, konsep sufisme Sasak menyatakan bahwa tingkat kepekaan seseorang akan terbangun dengan baik dari intensitasnya bangun pada sepertiga malam (tahajjud), terutama pada malam Senin dan malam Jumat (Fathurrahman, 2017:78).

\section{4) Kembang A ra}

Kembang Ara dikenal memiliki bunga yang tersembunyi dan sulit ditemukan. Kalau ditemukan bunga pada Kembang Ara, seseorang 
seolah akan mendapatkan ketrimen (bahasa Sasak). Ketrimen dimaknai sebagai suatu karunia seperti mendapat lailatul qadar. Orang tidak banyak tahu tentang bunga pada Kembang Ara. Memang terdapat bunga pada Kembang A ra tetapi sering tersembunyi oleh bakal buahnya. Secara sufisme Sasak, makna dari Kembang Ara ini adalah orang yang sudah tidak lagi memikirkan gaya dan penampilan dalam kehidupannya (sederhana dan apa adanya). Dengan kata lain, apa yang diperlihatkan bukan lagi sebagai suatu bentuk pencitraan, tetapi menunjukkan aslinya.

\section{5) Kembang Laos}

Kembang Laos bermakna sebagai orang yang mampu kembali terlahir sebagai orang yang fitrah dengan meninggalkan duniawi atau dalam pengertian lain ialah hidup secara zuhud. Nilai-nilai sufisme bangsa Sasak sangat relevan dengan nilai sufi secara umum. Hal tersebut karena memang Sasak itu sendiri adalah sangat dekat dengan aspek tasawuf universal. Jadi, bagi mereka yang sudah mampu meninggalkan nafsu duniawi itulah yang disebut sebagai Kembang Laos. Kembang Laos adalah juga perlambang dari penghormatan terhadap arwah nenek moyang dengan melakukan tradisi ziarah ke makam-makam yang dikeramatkan atau kemaliq. Ada banyak banyak makam yang kemaliq di gumi Sasak (Pulau Lombok).

\section{6) Kembang Serinata}

Kembang Serinata merupakan bunga yang langka sehingga saat ini agak sulit ditemukan. Secara sosial, keberadaan kembang ini sebagai pertanda untuk mengingatkan kita akan kearifan nilai-nilai luhur masa lalu dari nenek moyang. Tidak ada pengetahuan yang terlepas dari hikmah yang kita dapatkan dari tradisi luhur masa lalu. Dalam konsep sufisme Sasak, Kembang Serinata adalah kembang penuh hikmah dan kenangan. Serinata sebagai sebuah kembang senantiasa mengingatkan pada setiap orang bahwa semua peristiwa dalam hidup ini pasti ada hikmahnya. Hikmah terkadang baru disadari setelah mengingat akan kenangan pada suatu peristiwa yang telah berlalu.

\section{7) Kembang Kemuning}

Terpilihnya Kembang Kemuning sebagai simbol yang menyiratkan makna sufismeSasak karena ciri-ciri dan bentuk kembang ini memberikan pelajaran bagaimana seharusnya seorang muslim bergaul dengan muslim yang lain dalam kehidupan sehari-hari. Selain sebagai simbol nilai-nilai sufisme Sasak, dalam novel Sanggarguri juga dijelaskan dengan cukup detail bagaimana ciri-ciri dan bentuk kembang Kemuning sehingga sangat pantas dijadikan sebagai simbol dalam kaidah sufismeSasak.

\section{8) Kembang Purus}

Kembang Purus merupakan pohon dengan batang perdu berduri. Masyarakat sudah mulai tidak mengenal lagi jenis pepohonan ini. Bunganya berwarna putih, ringan, dan bisa diterbangkan. Biasanya tumbuh di antara batubatu cadas, baik di tempat kering maupun tempat basah, dan sering dimanfaatkan juga sebagai obat. Karakter pohon purus ini sangat tidak menarik dan jarang didekati orang karena berduri. Sufisme Sasak menangkap maknanya, yakni dalam kehidupan sehari-hari kita sering takut atau bahkan menganggap remeh hanya karena melihat pada penampilan luar sese orang. Namun demikian, pelajarannya ialah bahwa dalam kehidupan terdapat orang-orang yang dianggap biasa, sederhana, tidak dihiraukan, bahkan orang enggan dan takut untuk mendekati, namun di balik itu orang tidak tahu kelebihan dan keistimewaan atau manfaat yang dimiliki atau dikandung di dalamnya.

\section{9) Kembang Tunjung}

Kembang Tunjung berhubungan dengan kemampuan wirid seseorang yang dalam istilah Buddha dinamakan Prana. Orang-orang yang memiliki kemampuan wirid tinggi memiliki energi seperti yang dimiliki oleh para le luhur dalam usaha mempertahankan keyakinan menghadapi tekanan penguasa. Wirid se- 
benarnya adalah kemampuan untuk melatih dan mengontrol serta mengolah napas manusia untuk melahirkan energi positif. Energi positif tersebut akan tersebar di semua bagian tubuh sehingga ada prana di kepala, prana di dada, prana di tangan, prana di pusar, dan seterusnya yang kesemuanya merupakan teknik pengolahan napas untuk melahirkan energi positif serta melatih kepekaan rasa dan iman sehingga melahirkan atmosfir kebajikan. Dalam kaidah sufisme Sasak, Tunjung juga memberi manusia sebuah pelajaran bahwa secara umum orangorang biasa meletakkan perhatiannya pada hasil akhir.

\section{0) Sanggarguri}

Sanggarguri merupakan judul novel, nama kembang sekaligus merupakan simbolisasi tujuan akhir dari perjalanan para anggota pejalan tradisi dalam Novel Sanggarguri. Sanggarguri adalah perlambang dari keberadaan seseorang. Seseorang yang sesungguhnya ada tetapi sama sekali tidak dipedulikan. Walaupun sanggarguri ada di mana-mana, kehadirannya atau keberadaannya tidak diperhitungkan. Sanggarguri juga melambangkan sikap manusia dalam kehidupan sehari-hari yang terkadang melihat sesuatu atau keadaan orang lain yang aneh, namun sesungguhnya menyimpan keistimewaan yang jarang diketahui. Selain sebagai simbol keitimewaan atau kelebihan yang dimiliki oleh orang lain, dapat pula disebut sebagai simbol perlindungan atau kekuatan. Di lingkungan sekitar kita, Sanggarguri sering tumbuh di halaman, pematang, hutan, ladang, bahkan wilayah perkotaan. Hampir di semua tempat Sanggarguri dapat ditemukan, namun keberadaannya yang banyak sering tidak dihiraukan walaupun memiliki keistimewaan.

Selanjutnya berkaitan dengan peran sufisme Sasak di tengah kehidupan masyarakat di Pulau Lombok. Sufisme dan Sasak adalah dua kata yang tidak terpisahkan karena diasumsikan bahwa konsep Sasak itu sendiri adalah sufisme atau tasawuf. Dalam konsep sufisme,
Sasak atau tasawuf Sasak tidak terlepas dari landasan utamanya, yaitu spirit tauhid yang melahirkan pemikiran kosmologis. Konsep orang Sasak melalui pemikiran kosmologis ini melahirkan cara hidup, cara berpikir, cara berkata, cara bertindak, dan cara bersikap dalam usaha mencari dan menemukan jalan untuk kembali. Adapun yang dimaksud dengan jalan kembali, yakni yang disebut dalam konsep tasawuf Sasak sebagai Daya atau Daye. Daya dalam hal ini bermakna segala sesuatu yang melahirkan spirit. Tentunya yang melahirkan spirit atau daya adalah sumber dari segala sumber spirit serta yang melahirkan spirit, yakni Allah Swt.

Dalam konteks ini, makna bangse Sasak sebagai suatu bangsa seperti bangsa-bangsa lain di dunia adalah ekspresi diri sebagai individu maupun sosial sesuai amanat kemanusiaan yang dibawanya, yakni fitrah, sibghah, dan hanif (Fathurrahman, 2017:99). Dengan konsep sufisme seperti itulah bangse Sasak senantiasa terpelihara dalam iman dan keyakinan Islam dari masakemasa. Hingga saat ini, walaupun zaman telah berganti dengan segala dinamikanya, hampir di semua pelosok Pulau Lombok, terutama di desa-desa atau di wilayah kampung di perkotaan, ekspresi budaya dalam bentuk ritual-ritual adat yang bersendikan agama masih hidup dan tetap terpelihara. Nilai-nilai luhur dari nenek moyang seperti tindih, merang, maliq, dan seperangkat nilainilai luhur lain masih tetap diakui dan dipegang teguh oleh masyarakat di berbagai tempat di seluruh pelosok gumi Sasak (Lombok) dari masa ke masa.

$\mathrm{Hal}$ ini dibuktikan dengan banyaknya makam yang bertebaran di seluruh pelosok Lombok. Dari puncak gunung hingga pinggir pantai yang diyakini sebagai makam para auliya dan shalihin. Mereka adalah para ulama yang memimpin masyarakat Sasak dari zaman ke zaman, di antaranya ada yang diyakini sebagai pewaris kepemimpinan Pengulu Alim, sang kepercayaan Dewi A njani (mitologi Sasak) 
sebagai penjaga kosmos gumi Sasak. Banyaknya makam yang dihormati oleh masyarakat Sasak yang tersebar di seluruh wilayah pulau Lombok ini, baik yang teridentifikasi maupun tidak, merupakan karakteristik spiritualitas masyarakat Sasak. Spiritualitas semacam itu masih tampak hingga saat ini dengan semakin berkembangnya pengetahuan dan pengalaman beragama dan berbudaya pada masyarakat.

Berbagai hal yang digambarkan dalam penjelasan di atas adalah suatu realitas bahwa manusia Sasak sejak awal adalah penganut agama tauhid dalam hal ini adalah Islam. Orang Sasak zaman dahulu tidak mengenal dewa-dewa sehingga membuktikan bahwa agama orang Sasak bukan dari turunan pengaruh Hindu atau Buddha, apalagi animisme. Orang Sasak memahami Islam sebagai bentuk kepatuham masyarakat terhadap Sang Khalik untuk memegang amanah sebagai makhluk dan menghormati sesama makhluk yang kemudian terwujud sebagai konsep sufisme Sasak hingga saat ini.

Nilai-nilai kosmologi tauhid yang mendasari nilai-nilai sufismeSasak ini disampaikan dari satu generasi ke generasi berikutnya meIalui peran para Tuan Guru dan Ustadz sebagai pemimpin informal yang diterima oleh masyarakat. Pemimpin-pemimpin informal inilah se benarnya yang merupakan transformasi kepe mimpinan Sasak, yakni Penghulu pada masa lalu ke pemimpin masa kini berupa Tuan Guru. Dalam setiap dakwahnya, para Tuan Guru dan tokoh-tokoh agama lainnya senantiasa mengingatkan peran tauhid sebagai sebuah benteng iman yang harus dipegang teguh oleh orang Sasak. Seperti yang disampaikan dalam konsep sufisme Sasak bahwa betapa semua ini adalah milik-Nya, jagat semesta ini adalah milik-Nya, langit dan bumi beserta isinya adalah milikNya, bahkan sampai diri manusia juga adalah milik-Nya. Hal inilah yang memayungi nilainilai manusia Sasak, yang tercermin pula dalam nyel okaq atau ungkapan-ungkapan yang terkesan berkhayal atau dongeng semata. Akan tetapi, pada hakikatnya melalui nyelokaq itulah mereka para tetua (baloq, wayah, atau lokaq) mentransformasikan berbagai nilai Sasak yang diambil dari intisari Islam hakiki.

Seluruh yang dilakukan oleh tokoh-tokoh agama, tokoh adat, dan para tetua di masa lalu dalam menyampaikan dakwah atau petuah melalui media cerita berupa dongeng atau nyel okaq, sebenarnya sama konsepnya dengan yang dilakukan oleh para sufi yang memanfaatkan sastra sufisme sebagai media. Sastra sufisme adalah karya sastra yang di dalamnya dijabarkan paham-paham, sifat-sifat, dan keyakinan yang diambil dari dunia tasawuf. Ringkasnya, sastra sufisme adalah karya sastra bermuatan ajaran kesufian (A fifuddin, 2013:18). Tema dasar sastra sufistik atau sastra sufisme ialah "cinta Ilahi" (isyq). Gagasan mengenai isyq ini menduduki tempat utama di dalam pemikiran para sufi sejak awal perkembangan tasawuf sampai masa yang paling akhir.

Dalam sejarah tasawuf, sastra telah dipilih sebagai media dalam menyampaikan pengalaman kerohanian para sufi sejak awal. Terdapat banyak penjelasan tentang pengalaman mereka yang berkenaan dengan makrifat dan persatuan mistik yang disampaikan dalam bentuk anekdot-anekdot, kisah perumpamaan atau alegori, dan puisi. Sebagai pencinta keindahan sejati, mereka yakin bahwa karya seni yang bermutu tinggi dapat membangunkan cinta yang telah tidur di dalam hati, baik cinta yang bersifat duniawi dan inderawi maupun cinta yang bersifat ketuhanan dan ruhaniah (Hadi, 2001:10).

Dengan demikian, dapat dipahami bahwa peran para sufi dengan kreativitas tinggi melalui seni sastra termasuk folklor sejak lama dilakukan dalam rangka turut menyebarkan dan memperluas pengaruh I slam di seluruh penjuru nusantara, termasuk di Pulau Lombok. Faktor keberhasilan para pendakwah di Gumi Sasak, yakni guru tarekat, para Sufi, para Tuan Guru, ustadz, Lokaq, dan Penghulu di Gumi Sasak adalah karena mereka tidak pernah jauh 
dengan masyarakat sebagai jamaahnya. Dalam kehidupan sehari-hari, mereka begitu dekat, saling berbaur, saling bersilaturrahmi, dan menjadi bagian yang tidak terpisahkan dengan kehidupan masyarakat. Hal tersebut membuat mereka sangat memahami seluk-beluk jamaahnya beserta kondisi lingkungan sosial budaya masyarakatnya. M etodedakwah seperti ini pun menjadi salah satu wujud konsep sufismeSasak (NSG, 2014:31).

Adapun bahasan mengenai peran sufisme Sasak dari sudut sosial budaya tentunya sangat menarik dan relevan bila dihubungkan dengan konsep yang sangat erat kaitannya dengan sufisme Sasak, yakni paçr. A palagi dengan melihat perkembangan situasi dan kondisi masyarakat Sasak di Pulau Lombok hingga saat ini, perbincangan tentang peran sufisme Sasak tidak bisa dilepaskan dengan konsep paçr.

Berbagai masalah yang mengepung masyarakat Sasak sebagai dampak dari kemajuan ilmu pengetahuan dan peradaban modern me lahirkan gaya hidup individualisme dan materialisme. Oleh sebab itu, konsep tentang paçr yang menyangkut isu-isu lingkungan di pulau Lombok sangat strategis sebab berkaitan erat dengan kehidupan masyarakat. Saat ini, ketika masyarakat berbicara tentang rusaknya berbagai habitat flora dan fauna serta semakin langkanya persediaan air bersih sebagai akibat dari rusaknya kawasan hutan Rinjani, konsep tentang paçr menjadi sangat penting. Paçr se bagai sebuah konsep tentang keberadaan dan eksisitensi alam dan tanah air Sasak, sangat erat kaitannya dengan Rinjani sebagai pusat kosmologi gumi Sasak. Posisinya yang terletak di sebelah utara atau paçr daye tidak sekadar bermakna geografis arah utara, namun juga mengacu kepada pusat energi kosmos, yakni daye atau daya. Daya/daye, dari kata Jawa Kuno dan bermakna 'hati' dan 'jantung'. Dalam ke dudukannya sebagai pusat kosmos, Gunung Rinjani merupakan penanda berupa simbol yang melegenda sebagai wilayah paçr yang memberikan daya atau kekuatan, bisa juga bermakna memberikan kehidupan, kesuburan dan perlindungan untuk masyarakat bumi Lombok. Oleh sebab itu, sebutan Iain bagi gunung Rinjani adalah sebagai paçr beleq atau inen paçr dan pansek gumi (Induk Bumi) (NSG, 2014:29).

Selain isu-isu lingkungan, isu-isu lain menyangkut paer yang relevan dengan peran sufismeSasak adalah isu-isu yang menyangkut dampak-dampak sosial kemasyarakatan sebagai akibat perubahan peradaban dunia modern. Isu-isu tersebut antara lain; mulai goyahnya lembaga perkawinan, sistem kekerabatan yang berantakan, institusi dan lembaga sosial budaya yang hidup enggan mati tak mau, hilangnya etika dan keteladanan, merebaknya kekerasan dan paradoksial dalam masyarakat, dan individual ismedan materialisme yang merupakan dampak dari dinamika peradaban modern. Adapun fakta-fakta tersebut di atas adalah kenyataan yang terjadi di tengah-tengah masyarakat Sasak dewasa ini (Yamin, 2004:10).

Kegamangan kehidupan masyarakat serta keterasingan dengan kehidupan budaya sendiri tidak hanya terjadi di daerah perkotaan tetapi juga mulai melanda sebagian wilayah perdesaan di Pulau Lombok. Walaupun sejumlah kegiatan kebudayaan beberapa tahun terakhir menunjukkan geliat kebangkitan, namun masih bersifat euforia dan cenderung bernostalgia. Lebih lanjut, pembenahan ranah kebudayaan masih terbatas pada aspek-aspek atributif dan pragmatis, seperti pakaian, kesenian, prosesi-prosesi adat dan sejenisnya. Belum menyentuh aspek-aspek rancang-bangun yang bersifat strategis untuk kemajuan kebudayaan dan masyarakat pendukungnya. Akibatnya, semua berjalan sebagai suatu kegiatan yang bersifat simbolis semata. Dengan demikian, dapat dikatakan bahwa generasi muda Sasak dewasa ini terancam untuk kehilangan jati dirinya sebagai manusia Sasak karena cenderung gagal untuk belajar mengenal sejarah masalalu serta akar tradisi Suku Sasak yang sebenarnya. 
Generasi muda Sasak juga mulai terasa asing dengan sejumlah nilai-nilai kearifan budaya lokal yang sangat kaya karena masyarakat termasuk sekolah hampir tidak menyentuh wilayah itu. Hal ini sangat disayangkan karena nilai-nilai kearifan suku Sasak mestinya diwariskan dari generasi kegenerasi agar tidak terjadi kepunahan. Hal lain yang lebih penting lagi agar dapat dengan efektif berfungsi sebagai filter dalam membendung dampak modernisasi dan globalisasi.

Dalam hal ini, kandungan nilai sufisme atau tasawuf dalam Novel Sanggarguri tentunya sangat relevan dengan kondisi masyarakat Sasak secara umum. Salah satu kondisi masyarakat yang merupakan persoalan yang dialami masyarakat Sasak adalah persoalan feodalisme. Feodalisme menjadi persoalan karena bertentangan dengan prinsip-prinsip demokrasi dan keadilan. Feodalisme inilah yang juga masih terasa lekat di tengah-tengah masyarakat suku Sasak karena tipikal manusia Sasak masih berada dalam pengaruh sistem patrimonial yang bercirikan kepatuhan yang dalam akan perintah penguasa atau raja pada zaman dahulu sehingga rakyat cenderung hanya menjadi objek dari sistem yang berlaku.

Dengan demikian, masyarakat Sasak cenderung menjadi pasif, tidak memiliki inisiatif dan pada akhirnya pasrah dalam menerima nasib. Hal ini menjadikan masyarakat kurang memiliki prakarsa dalam menggerakkan potensi dalam mengubah kehidupan. Padahal, se lain kekayaan alam yang melimpah, sesungguhnya masyarakat Sasak di Pulau Lombok dianugerahi oleh potensi lain, yakni potensi modal-modal sosial yang dapat menjadi penggerak dalam mengubah kehidupan ke arah yang lebih baik. Modal sosial yang dimaksud adalah seperangkat nilai-nilai dan kearifan budaya lokal yang berpotensi menggerakkan dan memberdayakan masyarakat dalam pembangunan seperti semeton, tindih, maliq, mçrang, dan siru.
Dalam nilai tindih misalnya, terkandung makna yang menjadi salah satu pilar bagi lestarinya keserasian dan keseimbangan sosial dalam masyarakat Sasak sehingga melahirkan instrumen nilai sosial yang disebut siru. Siru menjadi jawaban terhadap kondisi masyarakat masa kini yang sudah kehilangan kepekaan sosial karena masyarakat saat ini terkesan individualis dan cenderung mendewa-dewakan materi. Siru juga menjadi jawaban terhadap mulai lunturnya nilai-nilai komunal yang selama ini menjadi modal sosial masyarakat, terutama di perdesaan.

Sebagai nilai kualitatif, siru merupakan wujud kesadaran manusia Sasak yang meyakini bahwa tidak satu pun makhluk di jagat ini yang keberadaannya tidak terkait dan terpaut dengan makhluk lainnya; kesalingtergantungan antarsesama makhluk merupakan prinsip dasar dari eksistensi. Nilai-nilai dalam besiru harus kembali ditanamkan oleh para orang tua dalam bale langgak (keluarga) masing-masing dengan kebiasaan saling bekerja sama dan bergotong royong untuk mengerjakan tugastugas rumah tangga sehari-hari dan tugas lainnya.

Besiru adalah bentuk praktis dari siru, yang dalam kehidupan sehari-hari manusia Sasak terwujud sebagai sikap dan laku "kesalingan"; saling tolong, saling memberi, saling jaga, saling didik, dan seterusnya. Sampai dengan 4 hingga 5 dekade yang lalu, dalam hal membangun rumah atau menggarap sawah misalnya, seseorang tidak perlu meminta bantuan kesana ke mari, sebab tanpa diminta, bantuan itu akan datang sendiri. Demikian pula halnya untuk berbagai sisi kehidupan lainnya, yang membutuhkan kehadiran orang lain.

Seperti juga masyarakat tradisional Iainnya, masyarakat Sasak memiliki kesadaran institutif. Simbol atau nilai dan institusi bagi mereka adalah satu mata uang dengan dua sisi. Mereka sangat menyadari bahwa kehadiran sekaligus simbol (nilai) dan institusi merupakan suatu keniscayaan. Semeton, tindih, maliq, 
mçrang, siru, dan sekian simbol lainnya, yang mereka ciptakan dalam rangka melestarikan Gumi Paçr Sasak, hanya mungkin disosialisasikan, dikontrol, dan dilestarikan melalui mekanisme institusi. Bale Langgak sebagai bagian salah satu institusi dasar dari konsep Gumi Paçr memegang peranan yang sangat penting dalam mengemban amanat tersebut.

Pada perkembangannya, sufisme Sasak dan perannya dalam kehidupan masyarakat dapat diartikan sebagai pemaknaan dan perwujudaan nilai-nilai dasar masyarakat Sasak yang juga sekaligus sebagai nilai-nilai sufisme Sasak. Hal ini sebagai upaya penyadaran orang Sasak akan nilai-nilai luhur yang dimiliki dan dioptimalisasikan sebagai modal sosial untuk perubahan dan pembangunan manusia Sasak seutuhnya. Konsep yang demikian sesuai de ngan pembangunan yang dikemukakan oleh A martya Sen, yaitu pembangunan yang membebaskan dengan maksud bahwa pembangunan yang difokuskan pada manusia yang menjalani dan seharusnya "menikmati" proses dan kegiatan pembangunan tersebut (Yamin, 2008).

Oleh sebab itu, nilai-nilai yang terkandung dalam sufisme Sasak sesungguhnya adalah modal sosial yang sangat berharga bagi pembangunan manusia Sasak, salah satunya pembangunan karakter bangsa Sasak. Nilai-nilai dalam Sufisme Sasak pada dasarnya sejalan dengan nilai-nilai yang ada dalam tasawuf secara umum. Di dalamnya terkandung semangat dan motivasi untuk berkembang dan maju dengan mengubah diri menjadi manusia yang mempunyai semangat untuk bekerja keras mengejar dunia namun tidak melupakan halhal yang bersifat ketuhanan. Demikian pula dengan modal-modal sosial yang dimiliki orang Sasak sangat dipengaruhi oleh nilai-nilai dalam tasawuf. Dengan kondisi seperti ini, upaya penumbuhan kembali spirit nilai-nilai lokal se bagai modal sosial yang efektif dalam bingkai sufisme Sasak sebagai penggerak pembangunan menjadi suatu keharusan agar potensi dan modal sosial masyarakat tidak menjadi tersiasiakan.

Di sinilah peranan lain yang dapat dimainkan oleh sufisme dalam kehidupan manusia Sasak. Perubahan prilaku masyarakat itu dapat dimulai dari sekolah, atau dari lingkungan yang lebih kecil lagi, yakni kelas melaui pembelajaran Sastra Indonesia misal nya. Nilai-nilai sufismeyang terkandung dalam Novel Sanggarguri pun selaras dengan nilai dan semangat dalam agama Islam, yakni semangat untuk untuk selalu berjuang, berkorban, dan bekerja, bukan sebaliknya menjadi pemalas dan melempem. Sufisme dalam Islam menyeru manusia mencari rezeki dan mengambil peran yang lebih besar dalam lapangan penghidupan sehingga dapat sejajar dengan bangsa-bangsa yang lainnya.

Selanjutnya, kembali keakar tradisi dengan memahami sejarah masa lalu serta nilai-nilai kearifan budaya lokal dalam masyarakat Suku Sasak adalah solusi alternatif dalam mengatasi problematika kehidupan masyarakat Sasak terkini. Hal ini akan sangat relevan jika dihubungkan dengan bagaimana sekolah-sekolah saat ini berupaya untuk menumbuhkan budi pekerti dan penguatan pendidikan karakter siswa. Dalam penguatan pendidikan karakter, salah satu upaya yang dapat ditempuh adalah mengintegrasikan nilai-nilai karakter ke dalam setiap mata pelajaran.

Kenyataan yang terjadi dewasa ini, sebagian dari generasi muda Sasak, khususnya pelajar mengalami keterasingan dengan nilai-nilai kearifan budaya lokal. Salah satu penyebabnya karena kurikulum pendidikan di sekolah dan juga budaya di sekolah kurang menyentuh wilayah kearifan lokal suatu daerah. Kurikulum 2013 yang dicanangkan pemerintah juga masih kurang mengakomodasi masuknya nilainilai kearifan lokal dalam muatan pelajaran, termasuk dalam pembelajaran Sastra Indonesia. Hal tersebut tentu sangat disayangkan karena nilai-nilai kearifan lokal, khususnya suku Sasak harus diwariskan dari generasi ke 
generasi agar tidak terjadi kepunahan, serta yang lebih penting lagi agar dapat dengan efektif berfungsi sebagai filter untuk membendung dampak modernisasi dan globalisasi.

Masa anak-anak merupakan masa yang sangat baik bagi terlaksananya pendidikan humaniora ini melalui penumbuhan pendidikan karakter yang baik. Hal ini sangat relevan dengan konsep yang disampaikan oleh Ratna (2014:540), yaitu secanggih-canggihnya teknologi yang berhasil dicapai, sebanyak-banyaknya materi yang berhasil diperoleh, setinggitingginya pangkat yang dimiliki, apabila masalah nilai manusia dan kemanusiaan tidak memperoleh tempat, tidak dihargai sebagaimana mestinya, kehidupan ini tidak ada harganya.

Dengan demikian, dapat dikatakan bahwa pendidikan humaniora melalui penumbuhan budi pekerti dan karakter inilah menjadi kunci dalam pendidikan di masa sekarang untuk membentengi anak dari perubahan dan pengaruh peradaban modern yang berlebihan. Anakanak yang terlahir dari pendidikan humaniora yang baik di bale langgak dengan nilai-nilai kultural masyarakat Sasak seperti yang tersebut di atas akan melahirkan dan membentuk masyarakat atau gubuk gempeng yang baik dan kuat pula. Argumentasi untuk itu bahwa setiap sikap, tutur-kata, dan perilaku akan terekam dan menjadi dokumentasi serta referensi setiap orang dalam komunitas untuk hari-hari selanjutnya. Oleh sebab itu, setiap orang harus selalu berupaya untuk menjadi teladan bagi sesama dan bagi lingkungan sosialnya.

\section{PENUTUP}

Sanggarguri sebagai sebuah karya sastra bernuansa lokal dan bercitarasa sufisme telah menjadi alat, media, dan wadah dalam rangka membuka pikiran manusia tentang hakikat hidup dan kehidupannya. Novel Sanggarguri memberikan nilai tambah bagi pemahaman terhadap paradigma karya sastra yang mengangkat situasi dan kondisi lokal suatu masya- rakat. Dalam hal lainnya, Novel Sanggarguri mengantarkan pembaca karya sastra menuju alam sufi yang mengombinasikan aspek sosial, kultural, dan spiritual. Melalui simbolisasi kembang atau bunga yang dalam kaidah kehidupan masyarakat Sasak merupakan sebuah pengagungan, Novel Sanggarguri memberikan beragam bentuk pembelajaran bagi masyarakat. Khususnya suku Sasak, Novel Sanggarguri hadir sebagai ikhtiar bersama dalam rangka mengembalikan nilai-nilai luhur yang mulai pudar akibat kurang dapatnya masyarakat beradaptasi dengan pesatnya perkembangan era digital.

Nilai-nilai yang dilambangkan melalui 10 jenis kembang di Pulau Lombok tersebut di antaranya saling menghormati, tidak meremehkan pihak lain, bersikap adil, teliti, bekerja sama dalam kebaikan, memberi manfaat dalam situasi dan kondisi apapun, hingga menjadi pegangan dan pengayom bagi masyarakat. Oleh sebab itu, simbolisasi yang dimaknai secara semiotik dan berdasarkan pada konsep sufisme Sasak tersebut harus menjadi pedoman bersama dalam menghadapi pesatnya perkembangan era digital yang telah memengaruhi berbagai bidang kehidupan berbangsa dan bernegara. Konsep yang ditawarkan melalui hasil penelitian ini tentu bersifat universal dan bukan hanya untuk golongan atau kelompok tertentu. Hal tersebut sesuai dengan amanat Sanggarguri, yaitu manusia mengajarkan kebaikan bukan untuk dirinya dan kelompoknya, tetapi kebaikan hakiki dan sejati harus menjangkau keseluruhan manusia dan makhluk lainnya. Dengan demikian, nilai sufisme Sasak juga dapat menjadi pedoman bagi masyarakat lainnya di luar suku Sasak atau Pulau Lombok.

\section{DAFTAR PUSTAKA}

Afifuddin. 2013. Sufisme Sasak dalam Bingkai Sosio-kultural. Mataram: Galih Kemuning. Amin, Syukur. 2014. Tasawuf Sosial. Yogyakarta: Pustaka Pelajar. 
Badrin, A hmad. 2011. "Potret Perjuangan Tokoh Utama dan Nilai Didik dalam Novel Guru D ane Karya Salman Faris" (Tesis Pascasarjana Universitas Mataram). Mataram: Unram Press.

Departemen Pendidikan Nasional. 2008. Kamus Besar Bahasa Indonesia (edisi III). Jakarta: Pusat Bahasa.

Effendi, Rahmad. 2017. M anusia di Era Digital. Yogyakarta: Jalasutra.

Endraswara, Suwardi. 2003. M etodologi Penelitian Sastra, Epistemologi; M odel Teori dan A plikasinya. Yogyakarta: Pustaka Widyatama.

Fathurrahman, A gus H.L. 2017. Kosmologi Sasak, Risalah Inen Paer. Mataram: Genius. Handayani. 2016. “Aspek Moral dalam Novel

Biru karya Fira Basuki: Pendekatan Semiotik" (Tesis Pascasarjana Universitas Mataram). Mataram: Unram Press.

Harapandi, Dahri. 2004. Pemikiran Teologi

Sufistik Syekh A bdul Q odir Jaelani. Jakarta: Wahyu Press.

Imron, Abdullah. 2013. "Nilai Pendidikan

Multikultural dalam Novel Burung-Burung

Rantau." (Tesis Pascasarjana Universitas Negeri Surabaya). Surabaya: Unesa Media. Jabrohim. 2003. M etodologi Penelitian Sastra. Yogyakarta: Hanindata Graha Widy.

Jumantoro, Totok. 2005. Kamus IImu Tasawuf. Yogyakarta: A mzah.
Mahjuddin. 2015. A khlak Tasawuf I. Jakarta: Kalam Mulia.

Nuriadi. 2016. Theory of Literature An Introduction. Mataram: Arga Puji Press.

Nurgiyantoro, Burhan. 2010. Teori Pengkajian Fiksi. Yogyakarta. UGM Press.

Ratna, Nyoman Kutha. 2011. Teori, M etode, dan Teknik Penelitian Sastra. Yogyakarta: Pustaka Pelajar.

Simon, Sidhey B, dkk. 2014. Values Clarification of Semiology. New York: Hart Publising Companay. Inc.

Siswantoro. 2015. M etode Penelitian Sastra: Analisis Psikologis. Surakarta: Muhammadiyah University Press.

Sunardi. 2012. Semiotika N egativa. Yogyakarta: Kanal Press.

Supaat, Lathief. 2010. Sastra Eksistensialisme, M istisme, Religius. Lamongan: Pustaka Pujangga.

Suriadin, Alwi. 2014. Islam Sufistik, Islam Pertama dan Pengaruhnya Hingga Kini di Indonesia. Bandung: Mizan.

Wachid, A bdul B.S. 2013. Sastra Pencerahan di Era M odern. Yogyakarta: Centra Grafindo. Wellek, Rene dan Austin Warren. 1995. Teori Kesusastraan. Jakarta: Gramedia

Yamin, M ochammad. 2014. Paer, Konsep D eososiokultural Sasak (Makalah pada Kongres Kebudayaan 2014). Jakarta: Kemdiknas. 